Article

\title{
Selective Mineralization and Recovery of Au(III) from Multi-Ionic Aqueous Systems by Bacillus licheniformis FZUL-63
}

\author{
Yangjian Cheng ${ }^{1} \oplus$, Zhibin Ke ${ }^{1}$, Xiaojing Bian ${ }^{1}$, Jianhua Zhang ${ }^{1,2}$, Zhen Huang ${ }^{1}$, Yuancai Lv ${ }^{1, *}$ \\ and Minghua Liu ${ }^{1, *}$ \\ 1 Fujian Provincial Engineering Research Center for High-Value Utilization Technology of Plant Resources, \\ College of Environment \& Resources, Fuzhou University, Fuzhou 350108, China \\ 2 Department of Environmental Engineering, Fujian Radiation Environmental Supervision Station, \\ Fuzhou 350003, China \\ * Correspondence: yclv@fzu.edu.cn (Y.L.); mhliu2000@fzu.edu.cn (M.L.)
}

Received: 25 April 2019; Accepted: 25 June 2019; Published: 28 June 2019

\begin{abstract}
The recovery of precious metals is a project with both economic and environmental significance. In this paper, how to use bacterial mineralization to selectively recover gold from multi-ionic aqueous systems is presented. The Bacillus licheniformis FZUL-63, isolated from a landscape lake in Fuzhou University, was shown to selectively mineralize and precipitate gold from coexisting ions in aqueous solution. The removal of $\mathrm{Au}(\mathrm{III})$ almost happened in the first hour. Scanning electron microscope with X-ray energy dispersive spectroscopy (SEM/EDS-mapping) results and fourier transform infrared spectroscopy (FTIR) data show that the amino, carboxyl, and phosphate groups on the surface of the bacteria are related to the adsorption of gold ions. X-ray photoelectron spectroscopy (XPS) results implied that $\mathrm{Au}(\mathrm{III})$ ions were reduced to those that were monovalent, and the $\mathrm{Au}(\mathrm{I})$ was then adsorbed on the bacterial surface at the beginning stage (in the first hour). $\mathrm{X}$-ray diffraction (XRD) results showed that the gold biomineralization began about $10 \mathrm{~h}$ after the interaction between $\mathrm{Au}(\mathrm{III})$ ions and bacteria. $\mathrm{Au}(\mathrm{III})$ mineralization has rarely been influenced by other co-existing metal ions. Transmission electron microscope (TEM) analysis shows that the gold nanoparticles have a polyhedral structure with a particle size of $\sim 20 \mathrm{~nm}$. The Bacillus licheniformis FZUL-63 could selectively mineralize and recover $478 \mathrm{mg} / \mathrm{g}$ (dry biomass) gold from aqua regia-based metal wastewater through four cycles. This could be of great potential in practical applications.
\end{abstract}

Keywords: selective biomineralization; recovery of $\mathrm{Au}(\mathrm{III})$; AuNP; Bacillus licheniformis FZUL-63; aqua regia-based metal wastewater

\section{Introduction}

Gold is a rare and precious metal that is widely used in various manufacturing industries, such as those of smart phones, personal computers (PCs), and other electrical printed circuit boards (PCBs) based electronic devices due to its excellent physical and chemical properties, electrical properties, high catalytic activity, and strong coordination ability [1-3]. However, huge amounts of electronic scraps are also generated because of the technological innovations and subsequent short lifetime of electronic devices $[4,5]$. PCBs are the key components and are considered the most valuable parts among electric and electronic equipment, since they contain precious metals at higher concentrations than natural high-grade ores. For example, PCBs used in smart phones and PCs contain gold with about $280 \mathrm{~g} /$ ton waste, which is very high compared to the $3-5 \mathrm{~g} /$ ton of gold in naturally occurring gold ores $[5,6]$. In addition, natural occurrences of these precious metals are limited and, in some mines, 
already depleted. Hence, to meet the increasing demand for gold, the separation and recovery of gold from PCBs must be undertaken. The recovery of precious metals like gold from secondary sources is quite important from economic and environmental points of view [4,7].

Conventional methods such as precipitation, ion exchange, solvent extraction, and flotation for gold recovery are available, but these methods have major disadvantages, like the use of toxic chemicals, high reagent requirements, and the generation of toxic secondary waste that requires disposal [8-11]. Various biomasses have been used as biosorbents for the recovery of precious metals, such as chitosan [12], proteins [13], eggshell membranes [14], and so on, but they have major limitations in terms of their low adsorption capacity, selectivity, and reusability [15-18].

Bio-mineralization is a natural phenomenon and the process by which living organisms produce minerals. Bacterial mineralization is generally selective for elements [19-21]. For example, magnetotactic bacteria synthesize magnetosomes by selectively absorbing iron ions in the surroundings [22,23]. Bacterial mineralization used to recover metals has gained a lot of attention because of its moderate reaction conditions, lack of toxic chemicals, and good metal selectivity [24-26]. It has been reported that Cupriavidus metallidurans is responsible for the formation of secondary gold nano-minerals in a periplasmic space, indicating that the production of secondary gold nano-minerals may be concerned with cell active reduction [27]. However, Delftia acidovorans induce gold ion mineralization by secreting delftibactin (a small molecule peptide) in solution [20]. Apart from the biological accumulation of Au nanoparticles (AuNPs) in prokaryotes, eukaryotes have also been reported to form gold nano-particles by biomineralization [26,28,29].

The development of a low-cost and eco-friendly method for the recovery of gold from multi-ionic aqueous systems via bacterial biosorption and bioreduction has gained a great deal of attention [15]. Recently, a number of researches on biosynthesis of gold nanoparticles by bacteria have indicated that the synthesized nanoparticles were stable and with controllable morphology [30]. Bacillus licheniformis has been studied for biosynthesis of gold nanocubes, which might apply in the field of biomedicine [31]. However, the mechanisms of such a process are still poorly understood. In this paper, the Bacillus licheniformis FZUL-63, isolated from a landscape lake in Fuzhou University, was shown to selectively mineralize and precipitate gold, and it was used to investigate the mechanisms of the bacteria-Au interactions process, as well as its selective adsorption and reduction of gold from coexisting ions in aqueous solution. Results showed that this bacterium could be of great potential in recovering $\mathrm{Au}(\mathrm{III})$ from multi-ionic aqueous systems.

\section{Materials and Methods}

\subsection{Microorganisms and Growth Conditions}

The strain FZUL-63, isolated from a landscape lake in Fuzhou University, Fuzhou, China (GPS location: $22^{\circ} 03^{\prime} 41^{\prime \prime} \mathrm{N}, 119^{\circ} 11^{\prime} 23^{\prime \prime} \mathrm{E}$ ), was identified through $16 \mathrm{~S}$ rDNA sequence homology analysis based on the standard procedure [32]. The strain FZUL-63 was cultivated in Luria-Bertani (LB) medium with $1 \%$ Tryptone, $0.5 \%$ yeast, and $1 \% \mathrm{NaCl}$ for $2 \mathrm{~d}$ at $30^{\circ} \mathrm{C}$. The cells were collected via centrifugation at $9000 \mathrm{rpm}$ for $10 \mathrm{~min}$ and the pellet was washed with $0.9 \% \mathrm{NaCl}$ three times, and the cells were then resuspended in the $0.9 \% \mathrm{NaCl}$ for variation analysis. In order to prevent the formation of silver chloride precipitation, we used purified water instead of $0.9 \% \mathrm{NaCl}$ to wash and re-suspend the cells that were acting with silver.

\subsection{Metal Ion Solution and Analysis}

All the chemicals used in this work were of analytical grade and were obtained from Sigma-Aldrich or Aladdin Industrial Corporation. Reagent grade water with a specific resistance of $18.2 \mathrm{M} \Omega \cdot \mathrm{cm}$ was obtained from a Milli-Q water purification system. The stock solutions (1000 mg/L) of $\mathrm{Au}(\mathrm{III})$, $\mathrm{Cu}(\mathrm{II}), \mathrm{Pt}(\mathrm{III}), \mathrm{Cr}(\mathrm{VI}), \mathrm{Pb}(\mathrm{II}), \mathrm{Ag}(\mathrm{I})$, and $\mathrm{Zn}(\mathrm{II})$ used in the experiments were prepared by dissolving $\mathrm{HAuCl}_{4} \cdot 3 \mathrm{H}_{2} \mathrm{O}, \mathrm{CuSO}_{4} \cdot 5 \mathrm{H}_{2} \mathrm{O}, \mathrm{HPtCl}_{4}, \mathrm{~K}_{2} \mathrm{Cr}_{2} \mathrm{O}_{7}, \mathrm{PbNO}_{3}, \mathrm{AgNO}_{3}$, and $\mathrm{ZnSO}_{4} \cdot 7 \mathrm{H}_{2} \mathrm{O}$ in purified water, 
respectively. The standard solutions ranging from 1 to $200 \mathrm{mg} / \mathrm{L}$ of the metal ions were prepared by diluting the stock solutions. Adjustment of $\mathrm{pH}$ was carried out using $0.1 \mathrm{~mol} / \mathrm{L} \mathrm{NaOH}$ or $0.1 \mathrm{~mol} / \mathrm{L}$ $\mathrm{HNO}_{3}$. The concentration of the metal ions was measured by inductively coupled plasma optical emission spectrometry (ICP-OES) (Optima 7000 DV, PerkinElmer, Waltham, MA, USA).

\subsection{Au(III) Uptake and Mineralization Experiments}

The harvested and washed bacterial cells were transferred into a $100 \mathrm{~mL}$ Erlenmeyer flask containing $30 \mathrm{~mL} \mathrm{Au}(\mathrm{III})$ solution $(200 \mathrm{mg} / \mathrm{L})$. The bacterial concentration was $0.05 \mathrm{mg} / \mathrm{mL}$ (dry weight) and the $\mathrm{pH}$ was maintained at 7 in the initialstage of the experiment. No nutrients were added to the reactors. Subsequently, the Erlenmeyer flask was incubated at $30{ }^{\circ} \mathrm{C}$ with a constant shaking speed of $160 \mathrm{rpm}$. Subsamples were collected at predetermined times and centrifuged at $5400 \mathrm{~g}$ for $10 \mathrm{~min}$. The supernatant samples were filtered through $0.22 \mu \mathrm{m}$ filters to remove $\mathrm{Au}$ (III) adsorbed on cell fragments. The residual Au(III) concentration in aqueous solution was determined by ICP-OES. All experiments were performed in triplicate.

The precipitates were freeze-dried and ground to powder in a mortar. The powder samples were analyzed by XRD (MiniFlex600, Rigahu, Japan) with $\mathrm{CuK} \alpha(\lambda=0.154 \mathrm{~nm})$, an incident beam monochromator, and power of $40 \mathrm{kV} \times 20 \mathrm{~mA}$ [33]. Diffractograms were obtained over a $2 \theta$ range of 5 to $80^{\circ}$ at a speed of $2^{\circ} / \mathrm{min}$. Peak identification was achieved with a standard profile fitting routine provided by Philips Netherlands. Qualitative identification of mineral phases was conducted utilizing the MDI Jade 7 software [34]. The average size of the metal gold particles was calculated by the Sherrer procedure.

TEM/EDS were employed to observe the distributions of gold on the bacteria cells. After the complete interaction of $\mathrm{Au}(\mathrm{III})$ (24 h of incubation), a $2 \mathrm{~mL}$ cellAu(III) suspension was taken from the $200 \mathrm{mg} / \mathrm{L} \mathrm{Au}(\mathrm{III})$ bio-removal experiment and centrifuged at $5400 \mathrm{~g}$ for $10 \mathrm{~min}$. The resulting cell pellet was washed three times with deionized water. JEOL JEM-2100 LaB6 TEM (JEOL, Peabody, MA, USA) with an accelerating voltage of $200 \mathrm{keV}$ fitted with STEM/EDS was employed for high-resolution imaging and for compositional analysis. To identify the reduced gold mineral, the selected area electron diffraction (SAED) pattern was acquired with a GatanOriusSC200D camera [35].

SEM and elemental mapping were employed to observe the distributions of gold on the bacteria cells. SEM observations were made to identify any morphological changes of B. licheniformis upon the exposure of $\mathrm{Au}(\mathrm{III})$ and to identify any mineral phase formed from $\mathrm{Au}(\mathrm{III})$ adsorption. Among the different $\mathrm{Au}(\mathrm{III})$ concentrations used for the adsorption experiment, the $200 \mathrm{mg} / \mathrm{L} \mathrm{Au}$ (III) sample was observed under SEM. Cells were first fixed for 20 min with $2 \%$ formaldehyde and $2.5 \%$ glutaraldehyde in a $0.05 \mathrm{~mol} / \mathrm{L}$ sodium cacodylate buffer ( $\mathrm{pH} 7.2)$ at a 1:1 ratio (sample: fixative). After this primary fixation, a few drops of sample suspension were placed over the surface of a glass cover slip and sequentially dehydrated using varying proportions of ethanol followed by critical point drying with a Tousimis Samdri-780A (Tousimis Research Corp., Rockville, MD, USA) critical point dryer (CPD). Critical point dried samples were coated with carbon using a Denton vacuum evaporator DV-502A (Denton Vacuum Inc., Moorestown, NJ, USA). A Zeiss Supra 35 VP SEM (Carl Zeiss, Jena, Germany) with Genesis 2000 X-ray energy-dispersive spectroscopy (SEM/EDS) was employed for cell imaging and compositional analyses.

\subsection{X-ray Photoelectron Spectroscopy (XPS) Analysis}

The chemical states of gold in the samples were measured by XPS. The powder samples of bacteria reacting with $\mathrm{Au}(\mathrm{III})$ for different times were placed in an evacuated sample chamber. Survey spectra were collected over the range of $0-1200 \mathrm{eV}$ with a pass energy of $30.0 \mathrm{eV}$. High-resolution XPS spectra were acquired for C1s [36]. All binding energy values were calibrated by using the value of contaminant carbon (284.65 eV) as a reference [37]. The spectra for Au were obtained under conditions of $0.05 \mathrm{eV}$ steps and analyzed after corrections. 


\subsection{Selective Mineralization Experiments}

The common metal ions in electroplating wastewater include $\mathrm{Au}(\mathrm{III}), \mathrm{Cu}(\mathrm{II}), \mathrm{Pt}(\mathrm{III}), \mathrm{Cr}(\mathrm{VI}), \mathrm{Pb}(\mathrm{II})$, $\mathrm{Ag}(\mathrm{I}), \mathrm{Zn}(\mathrm{II})$, and so on. The above-mentioned ions were prepared in every $100 \mathrm{~mL}$ Erlenmeyer flask by diluting the stock solution, respectively. The gold stock solution was added to the various Erlenmeyer flasks with the initial concentration of $200 \mathrm{mg} / \mathrm{L}$, except for the Erlenmeyer flask containing the $\mathrm{Ag}(\mathrm{I})$ solution, as $\mathrm{Ag}(\mathrm{I})$ ions cannot coexist with the $\mathrm{HAuCl}_{4} \cdot 3 \mathrm{H}_{2} \mathrm{O}$ solution. After adding the $\mathrm{Au}(\mathrm{III})$, the initial concentrations of $\mathrm{Cu}(\mathrm{II}), \mathrm{Pt}(\mathrm{III}), \mathrm{Cr}(\mathrm{VI}), \mathrm{Pb}(\mathrm{II}), \mathrm{Ag}(\mathrm{I})$, and $\mathrm{Zn}$ (II)were adjusted to $200 \mathrm{mg} / \mathrm{L}$ and the bacterial dosage was $1 \mathrm{~g}$ dry weight per liter in each $100 \mathrm{~mL}$ Erlenmeyer flask containing the $25 \mathrm{~mL}$ solution. Subsequently, the Erlenmeyer flasks were incubated at $30^{\circ} \mathrm{C}$ with a constant shaking speed of $160 \mathrm{rpm}$. Subsamples were collected at predetermined times and centrifuged at $5400 \mathrm{~g}$ for $10 \mathrm{~min}$. The residual ion concentrations in the supernatant were determined by ICP-OES and the pellets were analyzed by XRD and TEM, as mentioned above.

\subsection{Recovery of $A u(I I I)$ Formaqua Regia-Based Metal Wastewater}

As much other metal as possible was removed, except for gold ions from PCBs with nitric acid, the insoluble substance was collected and treated with aqua regia. Then, the $\mathrm{pH}$ was adjusted to 6.0 with $5 \mathrm{~mol} / \mathrm{L} \mathrm{KOH}$ and centrifuged. The metal ion concentrations in the supernatant, also called the aqua regia-based metal wastewater, were determined by ICP-OES, as mentioned above.

The bacteria were added to the supernatant with the amount of $1 \mathrm{~g}$ of biomass (dry weight) per liter. Subsequently, the Erlenmeyer flasks were incubated at $30^{\circ} \mathrm{C}$ with a constant shaking speed of $160 \mathrm{rpm}$. Subsamples were collected at predetermined times for analysis. In the reaction platform stage, bacteria and gold nanoparticles were collected by centrifugation at $5400 \mathrm{~g}$ for $10 \mathrm{~min}$, and the aqua regia-based metal wastewater was added to the collection containing bacteria and gold nanoparticles again. This was then cycled many times until the bacteria had less or no ability to mineralize $\mathrm{Au}(\mathrm{III})$.

\section{Results and Discussion}

\subsection{Au(III) Uptake and Mineralization}

The strain FZUL-63 was identified as Bacillus licheniformis through 16S rDNA sequence homology analysis. B. licheniformis removed $\mathrm{Au}(\mathrm{III})$ from aqueous solution as a function of time. B. licheniformis removed $\mathrm{Au}(\mathrm{III})$ from aqueous solution as a function of time, as shown in the graph of Figure 1a. In this process, the color of the culture in the Erlenmeyer flask turns from bright yellow to pink $(10 \mathrm{~h})$, and finally becomes wine red (Figure 1a), which was attributed to the formation of AuNPs. It is reported that gold nanoparticles show different colors according to different sizes (the bigger the particle size, the darker the color) [38]. The solid phase samples collected from different interaction times were analyzed by XRD (Figure 1b). In the first hour, no peaks were detected in XRD patterns after the interaction between bacteria and $\mathrm{Au}(\mathrm{III})$, suggesting that adsorbed $\mathrm{Au}$ (III) did not form crystalline phases. Although no crystalline phases were detected with XRD after a $1 \mathrm{~h}$ interaction, with a prolonged time, some weak peaks were observed in the XRD pattern after 10 hours of interaction, implying that a small amount of gold mineral formed (Figure $1 \mathrm{~b}$ ). The newly observed diffraction peaks matched well with gold. These results suggest that with time, the bacterium may have mediated $\mathrm{Au}(\mathrm{III})$ transformation from an amorphous compound to stable AuNPs. Under TEM, there were many AuNPs with a $\sim 20 \mathrm{~nm}$ grain size on and around the bacterial cell surface (Figure 1a). It was reported that bacterial metabolic activity might be inhibited by the toxicity of Au [20]. However, our colony counting experiments showed that after $30 \mathrm{~h}$ of interaction with $\mathrm{Au}$, the number of viable cells was not significantly reduced (before interaction: $3.6 \times 10^{8} \mathrm{CFU} / \mathrm{mL}$; after interaction: $2.9 \times 10^{8} \mathrm{CFU} / \mathrm{mL}$ ). Therefore, the cell metabolic activity might play a vital role in Au adsorption and mineralization process. 
(a)

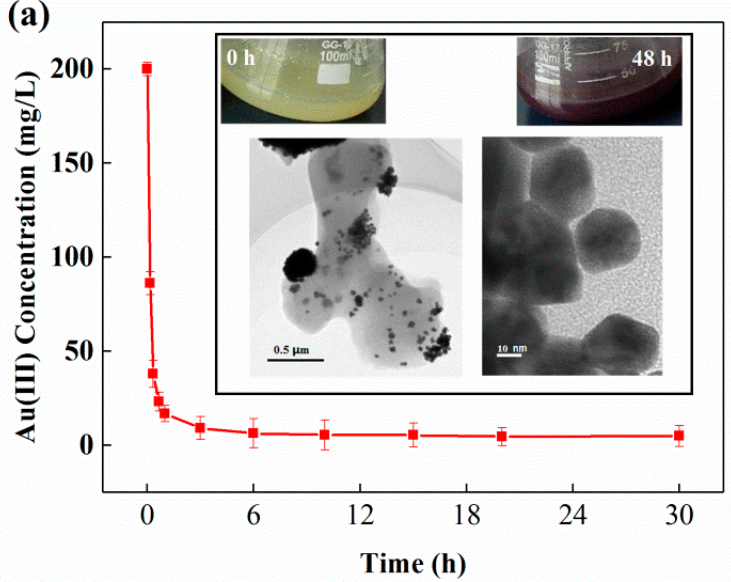

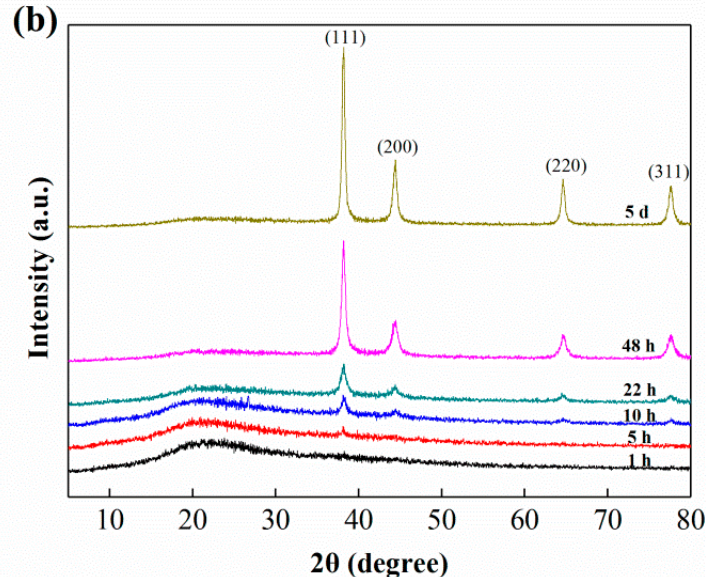

Figure 1. The interaction between bacteria and $\mathrm{Au}(\mathrm{III})$ with time. (a) The $\mathrm{Au}(\mathrm{III})$ concentration in aqueous solution. The inserts show the color of the culture (top) at $0 \mathrm{~h}$ and $48 \mathrm{~h}$, respectively; and TEM images of cells and Au particles (bottom) at 48 h. (b) XRD pattern of the AuNPs enhanced over time.

\subsection{The Chemical Groups Involved in Gold Binding}

The gold ions in the aqueous solution were quickly removed (Figure 1a), but the XRD results indicate that no minerals formed in the initial stage (Figure 1b), so the gold ions may have been adsorbed on the surface of the bacteria first. SEM/EDS-mapping was conducted to investigate spatial association between $\mathrm{Au}$ and $\mathrm{C}, \mathrm{O}, \mathrm{N}, \mathrm{P}, \mathrm{S}$ in the bacterial surface. As shown in Figure 2c,d, Au detected in the bacterial surface and was co-localized with $\mathrm{C}, \mathrm{O}, \mathrm{N}, \mathrm{P}, \mathrm{S}$, indicating involvements of functional groups which contain these elements during adsorption process.

To further elucidate the chemical groups involved in gold binding, FTIR spectra were recorded for control and gold-loaded cells from $4000 \mathrm{~cm}^{-1}$ to $400 \mathrm{~cm}^{-1}$ (Figure 2). The characteristic peaks can be assigned to the involvement of the main functional groups present in the bacterial biomass by analyzing the highly complex IR spectra (Figure $2 \mathrm{~h}$ ). The $\mathrm{N}-\mathrm{H}$ stretching peak that lies in the spectrum region occupied by a broad and strong band in the $3200-3600 \mathrm{~cm}^{-1}$ region was due to the presence of $\gamma \mathrm{O}-\mathrm{H}$ of the hydroxyl groups, which undergo change in the peak position in the gold loaded spectrum, suggesting the involvement of amino and hydroxyl groups in gold binding to the bacterial surface $[39,40]$. In the spectra for gold-loaded cells, the peak around $2366 \mathrm{~cm}^{-1}$ could be assigned to the $\mathrm{P}-\mathrm{O}$ stretching vibrations, implying a possible role of phosphate metabolism, facilitating the cellular adsorption of gold ions. The spectra for both control and gold-loaded samples revealed protein-related bands. The appearance of $\gamma \mathrm{C}=\mathrm{O}$ of amide I and the $\delta \mathrm{NH} / \gamma \mathrm{C}=\mathrm{O}$ combination of the amide II bonds that were present at $1652 \mathrm{~cm}^{-1}$ and $1543 \mathrm{~cm}^{-1}$, respectively, were predominant in the control spectrum. Following Au binding, the amide I absorption peak $\left(1652 \mathrm{~cm}^{-1}\right)$ was split into two minor peaks at $1664 \mathrm{~cm}^{-1}$ and $1639 \mathrm{~cm}^{-1}$ and a marked shift of the $1543 \mathrm{~cm}^{-1}$ peak to $1541 \mathrm{~cm}^{-1}$ suggests the interaction of Au with carboxyl groups. In the control spectrum, sharp peaks between $1400 \mathrm{~cm}^{-1}$ and $1500 \mathrm{~cm}^{-1}$ were due to the presence of the carboxyl groups [31]. Particularly, the strong peak at $1451 \mathrm{~cm}^{-1}$, which was characteristic of the scissoring motion of $\mathrm{CH}_{2}$ groups [32], underwent a shift to a lower energy level $\left(1449 \mathrm{~cm}^{-1}\right)$ after gold binding. Following gold uptake, a clear shift of the peak at $1399 \mathrm{~cm}^{-1}$ to $1388 \mathrm{~cm}^{-1}$ due to the symmetric stretching of COO- vibration strongly indicated a role of carboxyl groups in gold binding [40]. In the control spectrum, the strong peaks at $1238 \mathrm{~cm}^{-1}$ and $1062 \mathrm{~cm}^{-1}$ were observed due to vibrations of carboxyl and phosphate groups [41]. Following gold exposure, a clear shift of these peaks to $1234 \mathrm{~cm}^{-1}$ and $1057 \mathrm{~cm}^{-1}$ suggests the interaction of bound metals with carboxyl and phosphate groups. A gradual shift of the peak in control spectra at $1238 \mathrm{~cm}^{-1}$, because of asymmetric stretching modes of protonated polyphosphates and $\mathrm{PO}$ uncomplexed in phosphate diesters to $1234 \mathrm{~cm}^{-1}$ in gold-loaded samples, indicated the weakening of the $\mathrm{P}=\mathrm{O}$ character as a result of metal binding to the phosphates [41]. Changes in the peak position and intensity in the $800 \mathrm{~cm}^{-1}$ to 
$400 \mathrm{~cm}^{-1}$ region could be assigned to the formation of intense $(\mathrm{M}-\mathrm{O})$ and $(\mathrm{O}-\mathrm{M}-\mathrm{O})$ bonds $(\mathrm{M}=\mathrm{metal}$ ion) [39]. The overall IR spectroscopic analysis suggests that phosphate, carboxyl, and amide groups on bacterial cells are the dominant functional groups involved in the bacteria-gold interaction.
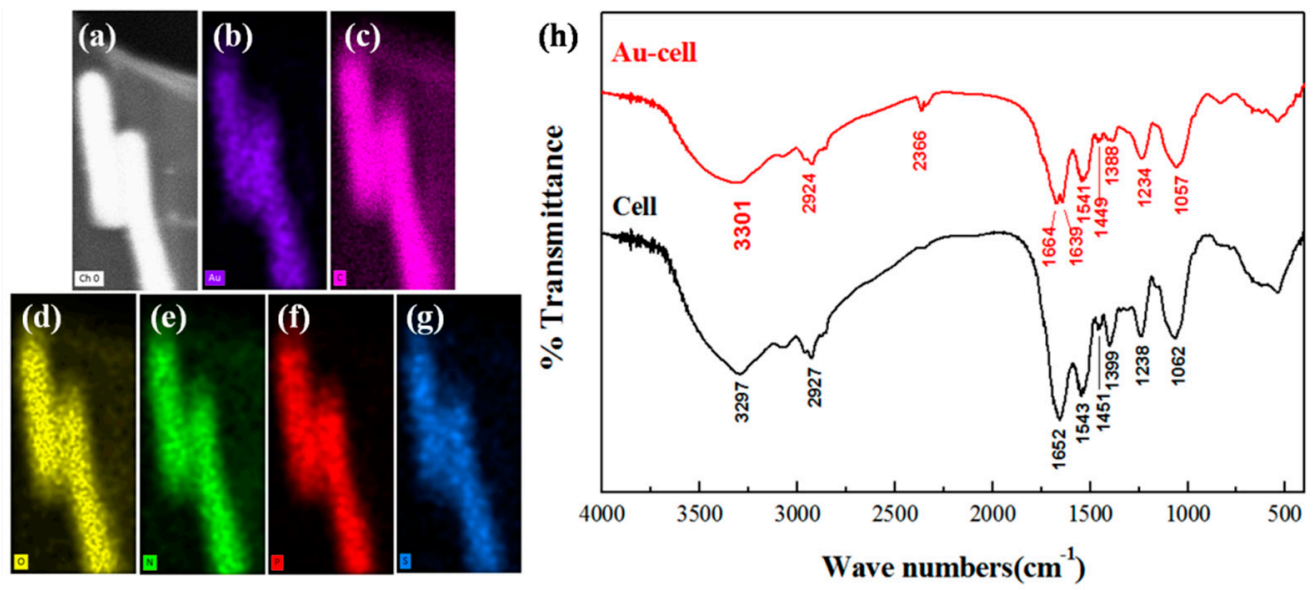

Figure 2. (a) SEM image of B. licheniformis FZUL-63 after interaction with gold; (b-g) elemental maps of $\mathrm{Au}, \mathrm{C}, \mathrm{O}, \mathrm{N}, \mathrm{P}$, and S, respectively; (h) Fourier transformed infrared spectra of B. licheniformis FZUL-63 biomass: before and after gold uptake (initial concentration of $200 \mathrm{mg} \mathrm{Au}$ (III) $\mathrm{L}^{-1}$ at $\mathrm{pH}$ 6.0, time $1 \mathrm{~h}$ ).

\subsection{Changes in the Chemical Valence State of Gold}

The interaction of $\mathrm{Au}(\mathrm{III})$ with bacteria at different times has been investigated by XPS. The Au 4f spectra of all the investigated samples are shown in Figure 3. The evidence is confirmed by the curve-fitting of the Au $4 \mathrm{f}$ core-level spectra by two spin-orbit split $\mathrm{Au} 4 \mathrm{f}_{7 / 2}$ and $\mathrm{Au} 4 \mathrm{f}_{5 / 2}$ components $(\mathrm{DE} \sim 4.0 \mathrm{eV}$ ), showing increasing BE values that correspond to a different chemical state of gold particles in the samples. With the initial addition of the chloric acid sample, the $A u 4 f_{7 / 2}$ photoelectronic peak is located at $\mathrm{BE}=84.38 \mathrm{eV}$ and this value is typical of $\mathrm{Au}(\mathrm{III})$ species, Figure 3a. After the interaction of the trivalent gold ions with bacteria, in the one-hour sample, shown in Figure $3 \mathrm{~b}$, the Au $4 \mathrm{f}_{7 / 2}$ spectrum consists of only one component located at $\mathrm{BE}=84.80 \mathrm{eV}$, which can be assigned to $\mathrm{Au}(\mathrm{I})$ species. In the 48-hour sample, the $\mathrm{Au} 4 \mathrm{f}_{7 / 2}$ peak detected at $\mathrm{BE}=83.81 \mathrm{eV}$ shown in Figure $3 \mathrm{c}$ can be attributed to the presence of $\mathrm{Au}(0)$ species on the bacterial surface. From the changes in the valence state after the action of trivalent gold ions and bacteria, it could be deduced that trivalent gold ions are not reduced to zero-valent gold (AuNP) in one step and the intermediates of monovalent gold compounds were produced in the reduced process.
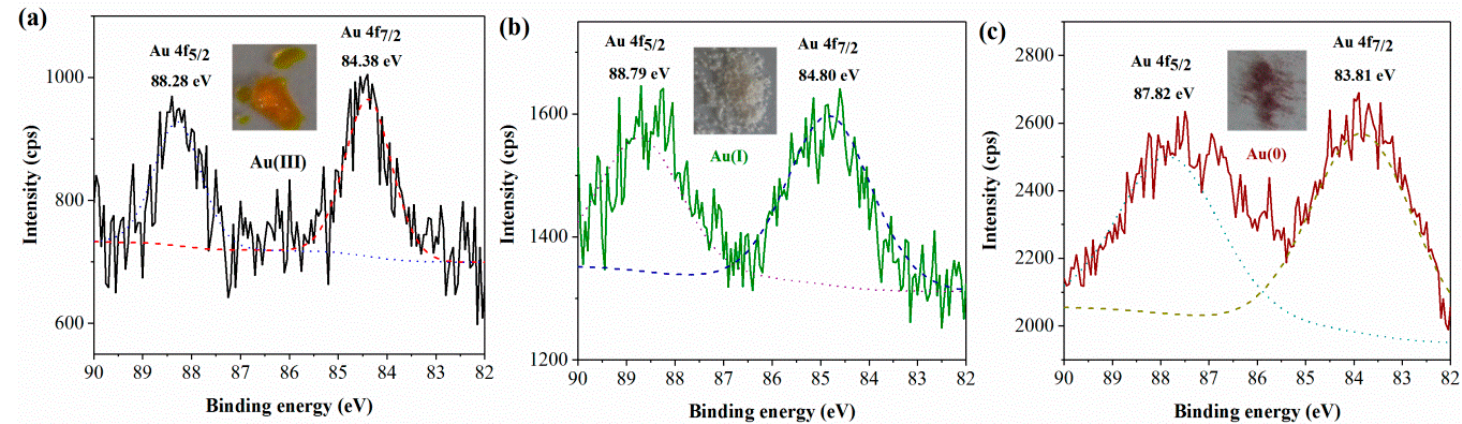

Figure 3. XPS spectra of the Au(4f) region of interaction with bacteria for (a) $0 \mathrm{~h}$; (b) $1 \mathrm{~h}$; and (c) $48 \mathrm{~h}$.

\subsection{Coexisting Ions Affect the Mineralization and Recovery of Gold}

The aqua regia-based metal wastewater usually contains the following metal ions: $\mathrm{Au}(\mathrm{III}), \mathrm{Pt}(\mathrm{III})$, $\mathrm{Ag}(\mathrm{I}), \mathrm{Cr}(\mathrm{VI}), \mathrm{Pb}(\mathrm{II}), \mathrm{Zn}(\mathrm{II})$, and $\mathrm{Cu}(\mathrm{II})$. The chloroauric acid and the silver ion cannot coexist in the 
solution. Therefore, we only conducted experiments using gold and silver acting alone with bacteria, and their recovery percentages were $97.66 \%$ and $49.23 \%$, respectively (Figure $4 \mathrm{a}$ ). The $200 \mathrm{mg} / \mathrm{L}$ $\mathrm{Cr}(\mathrm{VI})$ ions could delay the recovery balance time of the gold from one hour to $18 \mathrm{~h}$, and the recovery percentage of gold was also reduced from $97.66 \%$ to $91.93 \%$ (Figure $4 \mathrm{~b}$ ). $\mathrm{Zn}$ (II) and $\mathrm{Cu}$ (II) rarely influenced the $\mathrm{Au}(\mathrm{III})$ recovery (Figure 4c,d). However, for the $200 \mathrm{mg} / \mathrm{L} \mathrm{Pt}(\mathrm{III})$ or $\mathrm{Pb}$ (II) coexisting with $\mathrm{Au}(\mathrm{III})$, the recovery percentage of gold was reduced from $97.66 \%$ to $85.06 \%$ and $93.31 \%$, respectively (Figure 4e,f).

On the contrary, when these ions coexisted with the gold ions, the gold ions could preferentially adsorb on bacterial surface, leading to reducing adsorption of other ions. The removal percentage $\mathrm{Pt}$ and $\mathrm{Pb}$ ions have obvious reduction (Figure $4 \mathrm{c}, \mathrm{d}$ ). Compared with the removal percentage of $\mathrm{Pt}(\mathrm{III})$ and $\mathrm{Pb}(\mathrm{II})$ via bacteria alone, the removal percentage of $\mathrm{Pt}(\mathrm{III})$ and $\mathrm{Pb}$ (II) decreased from $45.82 \%$ to less than $0.5 \%$ and $56 \%$ to $17.33 \%$ in the presence of gold ions, respectively. The results indicated that $B$. licheniformis was able to preferentially adsorb and reduce $\mathrm{Au}(\mathrm{III})$ to $\mathrm{Au}(0)$ from multi ionic aqueous system. The reason for preferential adsorption and reduction might be the following two aspects: one is the cell metabolic activity; the other is the redox potential orders of metals.
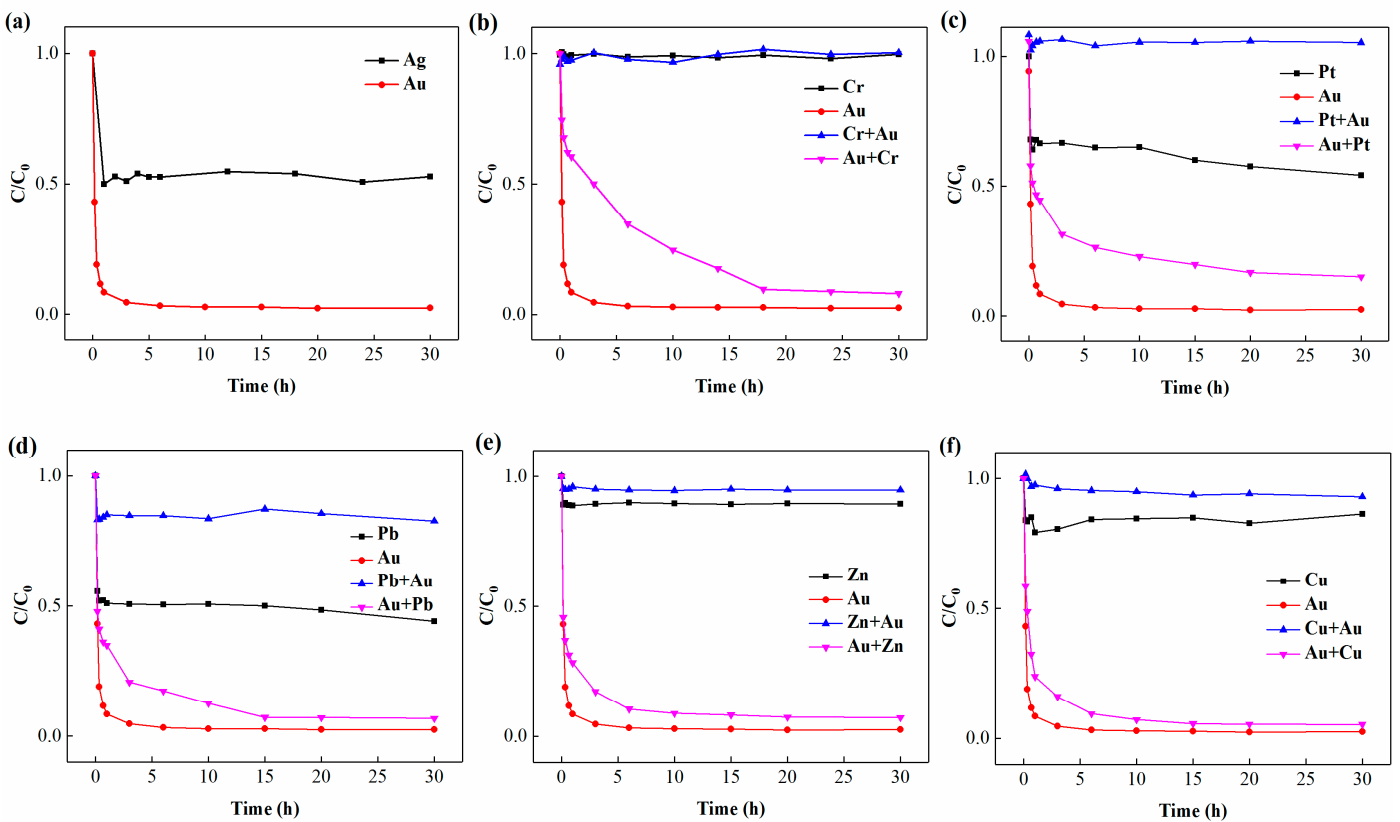

Figure 4. $\mathrm{Au}(\mathrm{III})$ recovery influenced by coexisting metal ions. (a) using gold and silver acting alone with bacteria. (b-f) using gold and other metal acting together with the bacteria. The initial concentration of each ion is $200 \mathrm{mg} / \mathrm{L}$, and the bacterial dosage is $1 \mathrm{~g}$ dry weight per liter. "Au + other metal" represent Au concentration while "other metal + $\mathrm{Au}^{\prime}$ is the concentration of other metal in the mixed solution.

\subsection{Recovery of $A u(I I I)$ Form Metal Wastewater}

The PCBs were treated with strong nitric acid. The insoluble substance was collected by centrifugation and treated with aqua regia. It was then adjusted to a $\mathrm{pH}$ of 6.0 and centrifuged. The concentration of ions in the supernatant was measured by ICP-OES, and the concentration of each ion before and after bacterial treatment is shown in Table 1. 
Table 1. Recovery of Au (III) from aqua regia-based metal wastewater in the first cycle.

\begin{tabular}{|c|c|c|c|c|c|c|c|c|c|}
\hline $\begin{array}{l}\text { Metal Concentration } \\
(\mathrm{mg} / \mathrm{L})\end{array}$ & $\mathrm{Au}^{3+}$ & $\mathrm{Cu}^{2+}$ & $\mathrm{Zn}^{2+}$ & $\mathrm{Pb}^{2+}$ & $\mathrm{Pt}^{4+}$ & $\mathrm{Cr}^{6+}$ & $\mathrm{Fe}^{3+}$ & $\mathrm{Ni}^{2+}$ & $\mathrm{Ag}^{+}$ \\
\hline With cell & $17.4 \pm 1.2$ & $330.7 \pm 2.5$ & $115.2 \pm 2.2$ & $34.3 \pm 1.7$ & $15.9 \pm 1.3$ & $26.1 \pm 1.9$ & $80.6 \pm 3.1$ & $47.3 \pm 2.7$ & ND \\
\hline
\end{tabular}

Note: ND indicates that the concentration is below the limit of detection. All experiments were performed in triplicate.

As Figure 5 shows, through the first treatment, the recovery percentage of gold was $90.4 \%$. After the second treatment, the gold recovery percentage dropped to $82.3 \%$. The gold recovery percentages were $61.8 \%$ and $29.6 \%$ at the third and fourth treatment, respectively. AuNPs could be recovered by acid dissolution. For example, the bacteria and gold nanoparticles were collected by centrifugation at $5400 \mathrm{~g}$ for $10 \mathrm{~min}$ and treated with $1 \mathrm{~mol} / \mathrm{L} \mathrm{HCl}$, which may dissolve the bacterial cells. Then, the acid dissolution sample was centrifuged at low rotation speed ( $2000 \mathrm{rpm}$ for $20 \mathrm{~min}$ ) to remove supernatant containing cell debris, DNA and so on. The pellet was gold particles with high purity. With four cycles, we could recover $478 \mathrm{mg}$ of AuNPs per gram of bacteria from the aqua regia-based metal wastewater.

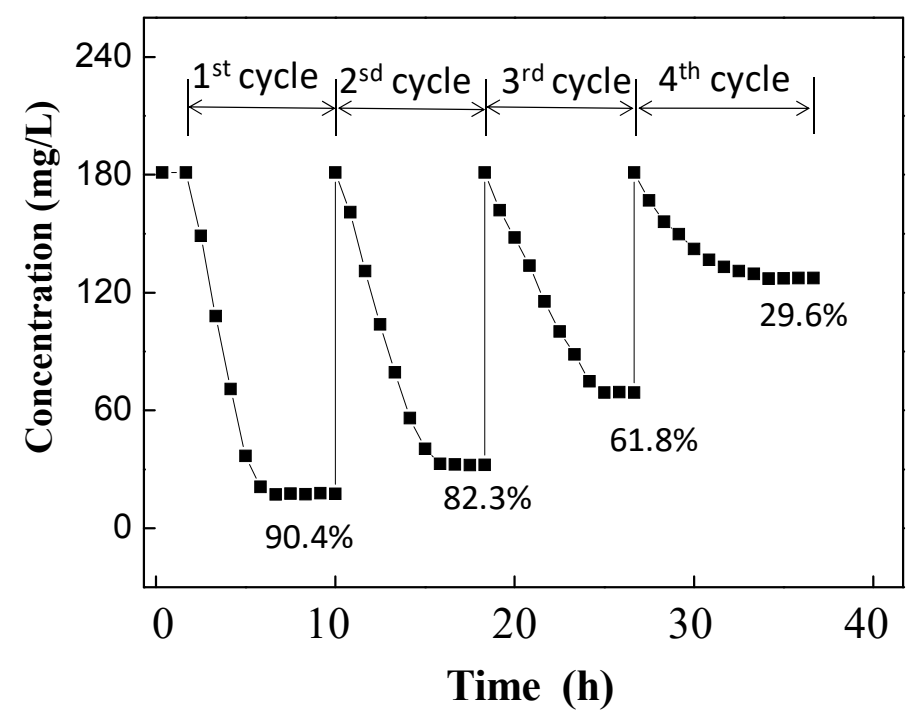

Figure 5. The Bacillus licheniformis FZUL-63 selectively mineralizes and recovers gold from aqua regia-based metal wastewater through four cycles.

\section{Conclusions}

An indigenous bacterium Bacillus licheniformis FZUL-63 was shown to selectively mineralize and precipitate gold from coexisting ions in aqueous solution. The process is as follows: $\mathrm{Au}(\mathrm{III})$ ions are reduced to those that are monovalent by the B. licheniformis, and the $A u(I)$ is then adsorbed on the bacterial surface in the beginning stage. The amino, carboxyl, and phosphate groups on the surface of the bacteria are related to the adsorption of gold ions. The gold biomineralization has rarely been influenced by other co-existing metal ions. The bacteria could recover $478 \mathrm{mg} / \mathrm{g}$ (dry biomass) of gold from aqua regia-based metal wastewater through four cycles.

Author Contributions: Conceptualization, Y.C.; methodology, H.Z.; investigation, X.B.; resources, J.Z.; data curation, Z.K.; writing—original draft preparation, X.B.; writing—review and editing, Y.C.; project administration, Y.L.; funding acquisition, M.L.

Funding: This work was financially supported by the National Basic Research Program of China (973 Program) (no. 2014CB846003), the National Natural Science Foundation of China (no. 41372346, 21477129), and the Natural Science Foundation of Fujian Province (no. 2019J01246). Additional support was provided by the China Scholarship Council (no. 201506655045) and the CSC-DAAD PPP Programmes for Project-Related Personal 
Exchange (no. 2019-12039). The funders had no role in the design of the study; in the collection, analyses, or interpretation of data; in the writing of the manuscript, or in the decision to publish the results.

Conflicts of Interest: The authors declare no conflict of interest.

\section{References}

1. Yin, P.; Xu, M.Y.; Qu, R.J.; Chen, H.; Liu, X.G.; Zhang, J.; Xu, Q. Uptake of gold (III) from waste gold solution onto biomass-based adsorbents organophosphonic acid functionalized spent buckwheat hulls. Bioresour. Technol. 2013, 128, 36-43. [CrossRef]

2. Fan, R.Y.; Xie, F.; Guan, X.L.; Zhang, Q.L.; Luo, Z.R. Selective adsorption and recovery of Au(III) from three kinds of acidic systems by persimmon residual based bio-sorbent: A method for gold recycling from e-wastes. Bioresour. Technol. 2014, 163, 167-171. [CrossRef]

3. Kwak, I.S.; Yun, Y.S. Recovery of zero-valent gold from cyanide solution by a combined method of biosorption and incineration. Bioresour. Technol. 2010, 101, 8587-8592. [CrossRef]

4. Hyder, M.; Ochiai, B. Selective recovery of $\mathrm{Au}(\mathrm{III}), \mathrm{Pd}(\mathrm{II})$, and $\mathrm{Ag}(\mathrm{I})$ from printed circuit boards using cellulose filter paper grafted with polymer chains bearing thiocarbamate moieties. Microsyst. Technol. 2018, 24, 683-690. [CrossRef]

5. Choudhary, B.C.; Paul, D.; Borse, A.U.; Garole, D.J. Surface functionalized biomass for adsorption and recovery of gold from electronic scrap and refinery wastewater. Sep. Purif. Technol. 2018, 195, 260-270. [CrossRef]

6. Van Eygen, E.; De Meester, S.; Tran, H.P.; Dewulf, J. Resource savings by urban mining: The case of desktop and laptop computers in Belgium. Resour. Conserv. Recy. 2016, 107, 53-64. [CrossRef]

7. Syed, S. Recovery of gold from secondary sources-A review. Hydrometallurgy 2012, 115, 30-51. [CrossRef]

8. Sheel, A.; Pant, D. Recovery of gold from electronic waste using chemical assisted microbial biosorption (hybrid) technique. Bioresour. Technol. 2018, 247, 1189-1192. [CrossRef]

9. Alzate, A.; Lopez, M.E.; Serna, C. Recovery of gold from waste electrical and electronic equipment (WEEE) using ammonium persulfate. Waste Manag. 2016, 57, 113-120. [CrossRef]

10. Natarajan, G.; Ting, Y.P. Gold biorecovery from e-waste: An improved strategy through spent medium leaching with $\mathrm{pH}$ modification. Chemosphere 2015, 136, 232-238. [CrossRef]

11. Yap, C.Y.; Mohamed, N. An electrogenerative process for the recovery of gold from cyanide solutions. Chemosphere 2007, 67, 1502-1510. [CrossRef]

12. Zhang, M.; Zhang, Y.; Helleur, R. Selective adsorption of $\mathrm{Ag}^{+}$by ion-imprinted O-carboxymethyl chitosan beads grafted with thiourea-glutaraldehyde. Chem. Eng. J. 2015, 264, 56-65. [CrossRef]

13. Maruyama, T.; Matsushita, H.; Shimada, Y.; Kamata, I.; Hanaki, M.; Sonokawa, S.; Kamiya, N.; Goto, M. Proteins and protein-rich biomass as environmentally friendly adsorbents selective for precious metal ions. Environ. Sci. Technol. 2007, 41, 1359-1364. [CrossRef]

14. Devi, P.S.; Banerjee, S.; Chowdhury, S.R.; Kumar, G.S. Eggshell membrane: A natural biotemplate to synthesize fluorescent gold nanoparticles. Rsc. Adv. 2012, 2, 11578-11585. [CrossRef]

15. Ju, X.H.; Igarashi, K.; Miyashita, S.; Mitsuhashi, H.; Inagaki, K.; Fujii, S.I.; Sawada, H.; Kuwabara, T.; Minoda, A. Effective and selective recovery of gold and palladium ions from metal wastewater using a sulfothermophilic red alga, Galdieria sulphuraria. Bioresour. Technol. 2016, 211, 759-764. [CrossRef]

16. Kaksonen, A.H.; Mudunuru, B.M.; Hackl, R. The role of microorganisms in gold processing and recovery-A review. Hydrometallurgy 2014, 142, 70-83. [CrossRef]

17. Das, N. Recovery of precious metals through biosorption-A review. Hydrometallurgy 2010, 103, $180-189$. [CrossRef]

18. Zhang, T.; Tu, Z.H.; Lu, G.N.; Duan, X.C.; Yi, X.Y.; Guo, C.L.; Dang, Z. Removal of heavy metals from acid mine drainage using chicken eggshells in column mode. J. Environ. Manag. 2017, 188, 1-8. [CrossRef]

19. Malhotra, A.; Dolma, K.; Kaur, N.; Rathore, Y.S.; Ashish; Mayilraj, S.; Choudhury, A.R. Biosynthesis of gold and silver nanoparticles using a novel marine strain of Stenotrophomonas. Bioresour. Technol. 2013, 142, 727-731. [CrossRef]

20. Johnston, C.W.; Wyatt, M.A.; Li, X.; Ibrahim, A.; Shuster, J.; Southam, G.; Magarvey, N.A. Gold biomineralization by a metallophore from a gold-associated microbe. Nat. Chem. Biol. 2013, 9, 241-243. [CrossRef] 
21. Nita, R.; Trammell, S.A.; Ellis, G.A.; Moore, M.H.; Soto, C.M.; Leary, D.H.; Fontana, J.; Talebzadeh, S.F.; Knight, D.A. Kinetic analysis of the hydrolysis of methyl parathion using citrate-stabilized $10 \mathrm{~nm}$ gold nanoparticles. Chemosphere 2016, 144, 1916-1919. [CrossRef]

22. Uebe, R.; Schuler, D. Magnetosome biogenesis in magnetotactic bacteria. Nat. Rev. Microbiol. 2016, 14, 621-637. [CrossRef]

23. Amor, M.; Busigny, V.; Louvat, P.; Gelabert, A.; Cartigny, P.; Durand-Dubief, M.; Ona-Nguema, G.; Alphandery, E.; Chebbi, I.; Guyot, F. Mass-dependent and -independent signature of Fe isotopes in magnetotactic bacteria. Science 2016, 352, 705-708. [CrossRef]

24. Lu, A.H.; Li, Y.; Jin, S. Interactions between semiconducting minerals and bacteria under light. Elements 2012, 8, 125-130. [CrossRef]

25. Pavlova, L.M.; Radomskaya, V.I. Biomineralization of precious metals. Biog. Abiogenic Interact. Nat. Anthropog. Syst. 2016, 15-27.

26. Narayanan, K.B.; Park, H.H.; Han, S.S. Synthesis and characterization of biomatrixed-gold nanoparticles by the mushroom Flammulina velutipes and its heterogeneous catalytic potential. Chemosphere 2015, 141, 169-175. [CrossRef]

27. Reith, F.; Etschmann, B.; Grosse, C.; Moors, H.; Benotmane, M.A.; Monsieurs, P.; Grass, G.; Doonan, C.; Vogt, S.; Lai, B.; et al. Mechanisms of gold biomineralization in the bacterium Cupriavidus metallidurans. Natl. Acad. Sci. USA 2009, 106, 17757-17762. [CrossRef]

28. Das, S.K.; Liang, J.; Schmidt, M.; Laffir, F.; Marsili, E. Biomineralization mechanism of gold by zygomycete fungi rhizopous oryzae. Acs. Nano. 2012, 6, 6165-6173. [CrossRef]

29. Lengke, M.F.; Fleet, M.E.; Southam, G. Morphology of gold nanoparticles synthesized by filamentous cyanobacteria from gold(I)-thiosulfate and gold(III)-chloride complexes. Langmuir 2006, 22, 2780-2787. [CrossRef]

30. Shedbalkar, U.; Singh, R.; Wadhwani, S.; Gaidhani, S.; Chopade, B.A. Microbial synthesis of gold nanoparticles: Current status and future prospects. Adv. Colloid. Interfac. 2014, 209, 40-48. [CrossRef]

31. Kalishwaralal, K.; Deepak, V.; Pandian, S.R.K.; Gurunathan, S. Biological synthesis of gold nanocubes from Bacillus licheniformis. Bioresour. Technol. 2009, 100, 5356-5358. [CrossRef]

32. Lin, W.T.; Huang, Z.; Li, X.Z.; Liu, M.H.; Cheng, Y.J. Bio-remediation of acephate-Pb(II) compound contaminants by Bacillus subtilis FZUL-33. J. Environ. Sci. China 2016, 45, 94-99. [CrossRef]

33. Cheng, Y.J.; Zhang, L.; Bian, X.J. Adsorption and mineralization of REE-Lanthanum onto bacterial cell surface. Environ. Sci. Pollut. Res. 2017, 25, 22334-22339. [CrossRef]

34. Cheng, Y.J.; Xu, X.Y.; Yan, S.G.; Pan, X.H.; Chen, Z.; Lin, Z. Hydrothermal growth of large-size UO2 nanoparticles mediated by biomass and environmental implications. Rsc. Adv. 2014, 4, 62476-62482. [CrossRef]

35. Singh, R.; Dong, H.L.; Liu, D.; Zhao, L.D.; Marts, A.R.; Farquhar, E.; Tierney, D.L.; Almquist, C.B.; Briggs, B.R. Reduction of hexavalent chromium by the thermophilic methanogen Methanothermobacter thermautotrophicus. Geochim. Cosmochim. Acta 2015, 148, 442-456. [CrossRef]

36. Bao, X.Q.; Qin, Z.; Zhou, T.S.; Deng, J.J. In-situ generation of gold nanoparticles on $\mathrm{MnO}_{2}$ nanosheets for the enhanced oxidative degradation of basic dye (Methylene Blue). J. Environ. Sci.China 2018, 65, 236-245. [CrossRef]

37. Miah, A.; Malakar, B.; Saikia, P. Gold over ceria-titania mixed oxides: Solar light induced catalytic activity for nitrophenol reduction. Catal. Lett. 2016, 146, 291-303. [CrossRef]

38. Kumar, S.A.; Peter, Y.A.; Nadeau, J.L. Facile biosynthesis, separation and conjugation of gold nanoparticles to doxorubicin. Nanotechnology 2008, 19, 495101. [CrossRef]

39. Choudhary, S.; Sar, P. Uranium biomineralization by a metal resistant Pseudomonas aeruginosa strain isolated from contaminated mine waste. J. Hazard Mater. 2011, 186, 336-343. [CrossRef]

40. Pagnanelli, F.; Papini, M.P.; Toro, L.; Trifoni, M.; Veglio, F. Biosorption of metal ions on Arthrobacter sp.: Biomass characterization and biosorption modeling. Environ. Sci. Technol. 2000, 34, 2773-2778. [CrossRef]

41. Jiang, W.; Saxena, A.; Song, B.; Ward, B.B.; Beveridge, T.J.; Myneni, S.C.B. Elucidation of functional groups on gram-positive and gram-negative bacterial surfaces using infrared spectroscopy. Langmuir 2004, 20, 11433-11442. [CrossRef]

(C) 2019 by the authors. Licensee MDPI, Basel, Switzerland. This article is an open access article distributed under the terms and conditions of the Creative Commons Attribution (CC BY) license (http://creativecommons.org/licenses/by/4.0/). 